\title{
Occupational Safety in Islamic Perspective
}

\author{
Amir Hayat* \\ Department of Islamic Studies \\ University of Lahore, Sargodha Campus, Sargodha
}

\begin{abstract}
Occupational Safety and Health (OSH), has gained much importance in the management of workplace. In the age of globalization and modernization safety and security has become very crucial in running a business smoothly and efficiently. All over the world governments issue various rules and regulations related to safety and security of employees for compliance. All the legislations and rules have common belief in a fundamental right of every employee to a healthy and safe working environment. Every responsible employer tries to abide by all the rules and regulations to have a good reputation in the world of business which ultimately results in greater profits. Islam views this world in different perspective. It goes beyond the materialistic needs of the businessmen and wants to treat employees only as human beings. The purpose of the present study is to explore the concept of occupational safety in Islamic perspective and highlight some of its principles which make it prominent from conventional occupational safety and health approach. The research work is theoretical in nature. The effort has been made in this research paper to look into the basic sources of Islam.
\end{abstract}

Keywords: Islam, occupational safety, workplace, hazards, human dignity, brotherhood, co-operation

\section{Introduction}

The origin of "The Industrial Revolution" in the late $18^{\text {th }}$ century and early $19^{\text {th }}$ century has changed the whole manufacturing setup of old household industry and manual work. The development of the factory system led to the tremendous change in the world of work. In the factories manufacturing of goods has been carried out on a scale and with speed never known before. ${ }^{1}$ This change in the way of work exposed workers to various industrial threats and dangers. During the early part of twentieth century working conditions in European and American factories were extreme adverse. Fatal accidents of workers including children and women were common. ${ }^{2}$ They often worked long hours

\footnotetext{
${ }^{*}$ Correspondence concerning the article should be addressed to Amir Hayat, (PhD), Department of Islamic Studies, University of Lahore, Sargodha Campus, Sargodha, amirhayat5817@gmail.com

${ }^{1}$ Sison, Payos and Zorilla, Personnel Management in the $21^{\text {st }}$ Century (Quezan City: Personnel Management Association of Philippines, Rex Printing Company, Inc., Philippines, $7^{\text {th }}$ edition, 2003 ), 8.

${ }^{2}$ Witzel, Management: The Basics (New York: Routledge, 2004), 74. 
Hayat, Occupational Safety in Islamic Perspective

and were used for such highly hazardous tasks as cleaning the machinery. They suffered from many industrial diseases due to overcrowded and unhealthy workshops. ${ }^{3}$

With the emergence of the concept of welfare state, governments changed their attitude towards workers and issued various regulations to provide basic rights and protections for workers. ${ }^{4}$ Moreover the miserable working and living conditions of workers ultimately led to the foundation of labour unions demanding radical reforms. ${ }^{5}$ Due to the bloody industrial disputes and labour unrest, the Western countries passed various legislations to ensure the safety and well-being of work people. In the age of globalization, business organizations operate in a tough and competitive business environment. Every successful organization today clearly recognizes the value of people for gaining a competitive advantage. Many famous organizations are successful because they pay a great deal of attention to the safety and well-being of their people. ${ }^{6}$ Recently the safety, security and health of working people have become the subject of increasing study and debate. Every business organization spends lot of money to ensure safety and security of their employees in order to keep its competitive advantage in the market; because every accident means loss of working hours and funds to support the injured or diseased employee.

The area of study concerns with the safety, health and welfare of people engaged in work is commonly known as occupational safety and health (OSH) or occupational health and safety (OHS) or sometimes has been termed as workplace, health and safety (WHS). Regardless of the combinations of words safety and health, one thing is clear that the goal of this field of study is to develop and promote safe and healthy workplace. ${ }^{7}$ According the Ministry of Overseas Pakistanis and Human Resource Development, occupational safety and health is defined as, "science of the anticipation, recognition, evaluation and control of hazards arising in or from work place that could impair the health and wellbeing of workers." 8 Today all over the world, employers have a common law duty to take reasonable care for the employees. The effort has been made in this article to examine the prevailing safety laws of Pakistan, and then look into the sources of

\footnotetext{
${ }^{3}$ Paul Mantoux, The Industrial Revolution in the Eighteenth Century (London: Methuen and Company Limited, n.d.), 410-417.

${ }^{4}$ Karen Legge, Human Resource Management: Rhetorics and Realities (New York: Palgrave Macmillan, Anniversary edition, 2005), 53. 1968), 560.

${ }^{5}$ Dalton E. McFarland, Personnel Management: Theory and Practice (New York: Macmillan,

${ }^{6}$ Michael R. Carrell, and Kuzmits, F. E. Kumits, Personnel: Human Resource Management (Columbus: Merrill Publishing Company, $2^{\text {nd }}$ edition, 1986), 2.

${ }^{7}$ Oak Ridge National Laboratory, retrieved from the website: http:// www.ornl.gov. on 30-10-2015

${ }^{8}$ Occupational Safety and Health: Legal Framework and Statistical Trend Analysis (2010-2015), Ministry of Overseas Pakistanis and Human Resource, 2016 (Islamabad: International Labour Standards Units, Ministry of Overseas Pakistanis and Human Resource Development, 2016 ), 5. http://ophrd.gov.pk/hrd/userfiles1/file/OSH.pdf
}

JOURNAL OF ISLAMIC THOUGHT AND CIVILIZATION

Volume 8 Issue $1 \quad 2018$ 
Hayat, Occupational Safety in Islamic Perspective

Islam to find out ways to motivate people to abide by the safety laws not as rule and regulations but also as religious obligation.

\section{Occupational Safety and Health Laws in Pakistan}

Pakistan is the sixth most populous country in the World with a population of about 189 million. ${ }^{9}$ The incidents of occupational diseases and injuries are $4 \%$ for the estimated labour force of 61 million. Safety laws in Pakistan are covered by the Factories Act of 1934. Section 3 of Factories act 1934 is related to the health and safety. It comprises of the laws related to the cleanliness, ventilation, artificial humidification, cooling, overcrowding, lighting, water, latrines and urinals, doors to open outwards, precautions against fire, means of escape, fencing, power to require specifications of defective parts or tests of stability, safety of building and machinery, restrictions of work near machinery in motion, power to exclude children. Moreover it also includes prohibition of employment of women and children near cotton-openers, notice of certain accidents, appeals, and power of Provincial Governments to make rules to supplement this chapter. ${ }^{10}$ However, the implementation of these regulations has always been a matter of debate in the countries such as Pakistan. The above stated laws are not up-todate, and further require improvements and suitable adjustments. "OSH (Occupational Safety and Health): Legal Framework and Statistical Trend Analysis," has observed that there is insufficient and unreliable data on occupational incidents, injuries and fatalities in Pakistan. On the other hand, there is little awareness among the employers as well as employees on the importance of OSH. Most of the causes of accidents/injuries belong to non-compliance of safety laws and regulations.

\section{Importance and Need of Occupational Safety in Islamic Context}

Islam offers unique perspectives on business and work. It views business and work activities as important and integral part of human life. ${ }^{11}$ Islam does not stand for life denial. Islam views work as means to sustain social prestige, to advance societal welfare and reaffirm faith. ${ }^{12}$ The role and importance of labour and manual effort has been described in the Holy Qur'ān in these words, "And that a man shall not deserve but (the reward of) his own effort."13

'Labour Force Survey 2014-15," Government of Pakistan, Statistics Division Pakistan Bureau of Statistics, 2015 (Islamabad: Government of Pakistan, Statistics Division Pakistan Bureau of Statistics, 2015), http://www.pbs.gov.pk/content/labour-force-survey-2014-15-annual-report; Occupational Safety and Health: Legal Framework and Statistical Trend Analysis (2010-2015), 37-38.

${ }^{10}$ Factories Act of Pakistan 1934, 28.

http://www.ilo.org/dyn/natlex/docs/WEBTEXT/35384/64903/E97PAK01.htm.

${ }^{11}$ Wahibur Rokhman, "The Effect of Islamic Work Ethics on Work Outcomes," EJBO Electronic Journal of Business Ethics and Organization Studies, vol. 15, no. 1 (2010): 22.

${ }^{12}$ Abbas J. Ali, Islamic Perspectives on Management and Organization: New Horizons in Management (Cheltenham: Edward Elgar Publishing Inc., U.K., 2005), 13.

${ }^{13}$ Al-Qur'ān: Al-Najam 53:39.

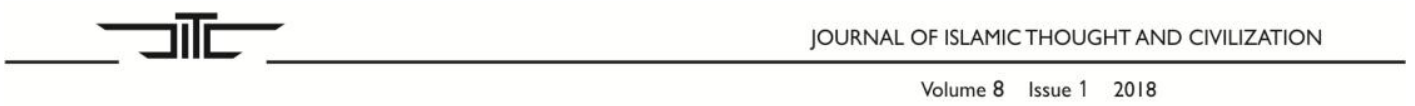


Hayat, Occupational Safety in Islamic Perspective

Holy Prophet $(S A W)$ made it clear to his companions that the dignity of human being is tied up with his work. It has been reported by al-Miqdām that Holy Prophet $(S A W)$ once said that, "Nobody has ever eaten a better meal than that which one has earned by working with one's own hands. One of the Prophets of Allah- David (Hazrat Musa A.S) used to eat from the earnings of his manual labour."14

Islam requires every individual to work and earn who is able and healthy and it is a religious and moral necessity as well. By engaging in economic activities through employment or trade Muslims can fulfil their religious obligation to please Allah. ${ }^{15}$ Therefore, work and employment in Islam is a religious obligation and is a form of worship (ibadah). ${ }^{16}$ Islamic perspectives on occupational safety are important because Islam plays a significant part in the lives of the Muslims. Everything which is backed by the Islamic teachings has sanctity in the lives of Muslims. It is also certain that organizations and their employees are influenced by the socio-political conditions of the country in which they operate. Work related behaviours, values and attitudes are considered to be the part of the cultural identity of a nation. These beliefs and values are carried into the workplace as cultural baggage of the employees. ${ }^{17}$ National culture of the country influences various rules and regulations governing employee management relations, such as, work schedules, health safety and environment, employment economic security.

In most of the Islamic countries the influence of Islam is substantial on national culture. According to the teachings of Islam man's social behaviour must be restricted and guided by the Laws of Allah. ${ }^{18}$ Due to its comprehensive nature, Islam in the Muslim countries plays a dominant role in the socio-political and legal system of the country. In a Muslim majority population country, Islam via national culture influences organizations. It appears that in countries where Islam plays such a role; there would be an extensive influence on religion of Islam on the workplace behaviour. Islam sets some fundamental ethical standards which are the best codes of ethics and model behaviour to put into practice. ${ }^{19}$ It is not possible for the organizations to ignore cultural and religious impact on workplace behaviour in a highly competitive environment of the $21^{\text {st }}$ century. Diverse

\footnotetext{
${ }^{14}$ Muhammad b Ismail Bukhari, Sahih al-Bukhari, "The Book of Sales (Bargains)," Chapter 15. "The Earnings of a Person and his Manual Labour," 2072, 168/3.

${ }^{15}$ Kabir Hassan and William J. Hippler, "Entrepreneurship and Islam: An Overview," Economics in Practice, vol., 11 (2) (2014):171.

${ }^{16}$ Toseef Azid, Mehmet Asutay, Umar Burki, "Theory of the Firm, Management and Stakeholders: An Islamic Perspective,” Islamic Economics Studies, vol. 15, no. 1 (July 2007):19.

${ }^{17}$ Munir Tayeb, "Islamic Revival in Asia and Human Resource Management," Employee Relations, vol. 19, no. 4 (1997): 352.

${ }^{18}$ Syed Nawab Haider Naqvi, Individual Freedom, Social Welfare and Islamic Economic Order, (Islamabad: Pakistan Institute of Development Economics, Pakistan, $1^{\text {st }}$ Edition, 1981), 7.

${ }^{19}$ Osman Chuah Abdullah, Muhammad Shuhaimi bin Haji Ishaq, "Conceptual Framework of Good Management from the Islamic Perspective," International Journal of Business and Management Studies, vol. 4, no. 1 (2012): 187.
} 
Hayat, Occupational Safety in Islamic Perspective

issues faced by contemporary organizations such as safety, security and health of employees to ensure good corporate governance must be dealt with the core values and ethics of Islam. ${ }^{20}$

\section{Islamic Approach to Occupational Safety}

Islam presents a complete solution to the problem of compliance to safety and security regulations through ethical and spiritual instructions and concern about the Hereafter. ${ }^{21}$ It lays great stress on the ethical and spiritual interpretation of economic problems. However, its ethical code is not merely an advice but constitutes the status of a legally binding command or decree, and the punishments or rewards are dealt out on the Day of Judgement in the light of these acts. Legal provisions without moral support are of little practical importance. Islamic teachings are forceful legal injunctions from the standpoint of Hereafter. ${ }^{22}$ The belief in the hereafter and the Day of Judgement has backed the Islamic penal code. According to Islamic approach every evil and wrong doing cannot be dispelled through the threat of punishment in this world, unless and until man bears the fear of the violation of commands of Allah and accountability on the Day of Judgement. According to Islamic teachings, any status of human being in this world in the form of an employee or employer is the test for him. ${ }^{23}$ Allah himself says in Qur'ān, "It is He who made you the vicegerents of the earth and raised some of you in ranks over others, so that He may test you in what He has given you. Surely, your Lord is swift in punishing, and surely He is Most-Forgiving, Very-Merciful."24

Concern of the hereafter is of fundamental importance to every Muslim because his ultimate success or failure depends upon his observance of the moral standards encouraged by Islam. ${ }^{25}$ Islam presents the concept of life after death and the Day of Judgement. Islam realizes the entrepreneurs that they are answerable to the Supreme Lord and they have to justify their actions on the Day of Judgement.

\section{Principles of Occupational Safety and Health in Islam}

Following are the key principles described by Islam regarding motivating people to express safety behaviour at the workplace.

${ }^{20}$ Khaliq Ahmed, "Challenges and Practices in Human Resource Management of the Muslim World," The Journal of Human Resource and Adult Learning, vol. 4, no. 2 (December, 2008): 34.

${ }^{21}$ Hakim Muhammad Said, The Employer and the Employee: Islamic Concept (Karachi: Dar alFikr al-Islami, Pakistan, $1^{\text {st }}$ edition, 1972), 90.

${ }^{22}$ Muhammad Ramzan Akhter, “An Islamic Framework for Employer-Employee Relations," The American Journal of Islamic Social Sciences 9:2, (1992): 213.

${ }^{23}$ Toseef Azid, "The Concept and Nature of Labour in Islam: A Survey," Review of Islamic Economics, vol. 9, no. 2 (2005): 105.

${ }^{24}$ Al-Qur'ān: Al-Anā'm (6): 165.

${ }^{25}$ Akhter, "An Islamic Framework for Employer-Employee Relations," The American Journal of Islamic Social Sciences, 213. 
Hayat, Occupational Safety in Islamic Perspective

\subsection{Human Dignity}

Islamic concept of occupational safety stems from its concept of dignity of man. Human dignity in Islamic terminology means that human being is inherently a venerated, esteemed and honoured creature. ${ }^{26}$ According to the view of Islam man enjoys special status in the universe. He is not an ordinary creature like other creatures of the universe. $\mathrm{He}$ is the focus and central object of the universe. ${ }^{27}$ In view of Islam human beings are granted of special divine favours. ${ }^{28}$ Dignity of man implies sacredness of the human person. ${ }^{29}$ According to the Islamic ideology Man is prime creation of Allah. He is not among the other animals nor is he a developed monkey. ${ }^{30} \mathrm{He}$ is the best of all the creatures. As for as the physical body is concerned, Man has been given the fines body which no other living being has been given. ${ }^{31} \mathrm{He}$ is combination of body and the spirit or the soul. ${ }^{32}$ Man has been endowed with a sense of moral insight. He is given the ability to judge what is good and what is wrong by means of natural inspiration. ${ }^{33}$. He has been endowed him with the ability to differentiate between good and evil naturally. ${ }^{34}$ Man is distinctive among other living creations in the universe with regard to his highest capacity to acquire knowledge. He is equipped with the potentials to explore the universe. 35 Man being a knowledgeable creation and having an excellent physical body and intellect; Allah Almighty has made him superior to all of his creations. ${ }^{36}$ Whole of this universe and everything in it is created for man.

Qur'ān states that all the special favours of Allah upon man are to prepare him for the role of deputyship of Allah in the universe. The real dignity and honour of man is that Allah Almighty has appointed him as His vicegerent on the earth to fulfil certain objectives through obeying his commands. ${ }^{37}$ It is obvious that Man enjoys special status in this universe. He is not among other factors of production. He should be treated as an

\footnotetext{
${ }^{26}$ Behrouz Yadollahpour, "Human Dignity and its Consequences in the Holy Qur'ān," IPEDR International Conference on Sociality and Economics Development vol. 10, No. 1 (2011): 551. http://www.ipedr.com/vol10/103-S10081.pdf.

${ }^{27}$ Syed Nawab Haider Naqvi, Ethics and Economics: An Islamic Synthesis (Leicester: The Islamic Foundation, United Kingdom, $1^{\text {st }}$ Edition, 1981), 45.

${ }^{28}$ Mohammad Hashim Kamali, "Human Dignity in Islam" (paper presented at the International Conference on Pathway of Human Dignity: From Cultural Tradition to a New Paradigm, jointly organized by Europe Science Foundation (ESF) and Linkopeng University, Vadstenna, Sweden, $1^{\text {st }}$ November, 2007), 2. Available online at www.iais.org.my

${ }^{29}$ Kamali, "Human Dignity in Islam," 1.

${ }^{30}$ Al-Qur'ān: Maryam 19:67.

${ }^{31}$ at-Tīn 95:4.

${ }^{32}$ al-Sajdah 32:9.

${ }^{33}$ as-Shams 91:7-8.

${ }^{34}$ al-Balad 90:10; Al-Qiyamah 75:2.

${ }^{35}$ al-Ālaq 96:4-5.

${ }^{36}$ al-Isra 17:70.

${ }^{37}$ Muhammad Taqi Usmani, An Introduction to Islamic Finance (Karachi: Arham-Shamsi Publication, 2004), 9.
}

JOURNAL OF ISLAMIC THOUGHT AND CIVILIZATION

Volume 8 Issue $1 \quad 2018$ 
Hayat, Occupational Safety in Islamic Perspective

honourable being at the workplace and should not be engaged in such tasks which are against his dignity.

\subsection{Honour of Human Life}

It is birth right of all human beings to live safely in this world. Killing is condemned as Allah says, "Do not kill any person the life of whom is sanctified by Allah, except for a just reason." 38

Human life is so much honourable and respected in the eye of Allah that the killing of one person is regarded as killing of whole of the human kind. whoever kills a person not in retaliation for a person killed, nor (as a punishment) for spreading disorder on the earth, is as if he has killed the whole of humankind, and whoever saves the life of a person is as if he has saved the life of the whole of humankind. ${ }^{39}$ The Holy Prophet $(S A W)$ at the time of last sermon declared that "Allah has made your blood, your properties and your honour sacred to one another (i.e., Muslims) like the sanctity of this day of yours, in this month of yours, in this town of yours."40

To secure this fundamental right of human kind employers have obligation to take care of the lives of their employees. It is their duty to provide safe working condition to the employees. They should manage their workplace such that the employees can perform their duties in safe and sound manner. It is the basic right of every employee that employer must provide them safe and healthy working environment.

\subsection{Brotherhood}

The workplace culture created by Islamic teachings is based upon the principles of equality, brother hood, justice and fairness. Qur'ān declares all believers as brothers. ${ }^{41}$

The Prophet Muhammad ( $S A W)$ has been reported to have said, "None of you will have faith till he wishes for his (Muslim) brother what he likes for himself." 42 Islam unites all members of the mankind in the bond of brotherhood as if they were members of one single family. Another report from Holy Prophet $(S A W)$ states that, "A Muslim is a brother of another Muslim, so he should not oppress him, nor should he hand him over to an oppressor." 43

${ }^{38}$ al-Isra 17:33.

${ }^{39}$ al-Maidah 5:32.

${ }^{40}$ Sahih Al-Bukhari, "The Book of Al-Adāb (Good Manners)," Chapter. 43, "o! you who believe! Let not a group scoff at another group..." (V.49:11), (6043), 48-49/8.

${ }^{41}$ Al-Qur'ān: Al-Hujurāt 49:10.

${ }^{42}$ Sahih Al-Bukhari, "The Book of Belief (i.e., Faith)," Chapter (7). "To Like for one's (Muslim's) brother what one likes for himself is a part of faith," (13), 60-61/1.

${ }^{43}$ Sahih Al-Bukhari, "The Book of al-Mazalim (The Oppressions)," Chapter 3, "A Muslim should not oppress another Muslim, nor should he hand over to an oppressor," (2442), 361/3.

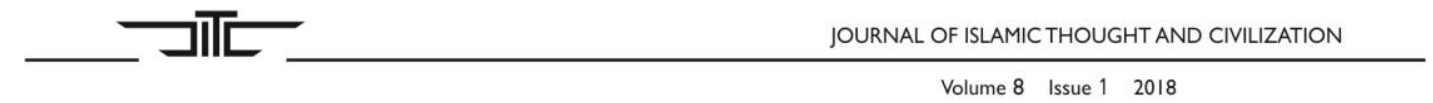


Hayat, Occupational Safety in Islamic Perspective

According to above injunctions, then, employers and employees are individual members of one brotherhood. ${ }^{44}$ The employers should treat their employees as their real brothers. A brother cannot rest in peace when he sees his own brother in distress. Therefore, according to Islamic injunctions a Muslim employer should not rest in peace if his labourers are in poor working conditions and are facing work hazards.

\subsection{Mercy and Kindness}

Mercy and kindness are placed high in the teachings of Islam. Islam wants to eradicate all types of exploitation and wrongdoing from the management process. ${ }^{45}$ Holy Qur'ān states in this regard, "And I do not want to put you in any trouble; you will find me, Insha'Allah (God-willing) one of the righteous." ${ }^{46}$

Islam emphasizes that the employer should be considerate, just and kind, and must purge his heart of the feelings of harness and cruelty. He should be forgiving and accommodating. This is not only good for him but is also conducive to the creation of a harmonious spirit between him and his employees. Prophet $(S A W)$ instructed his companions to be kind and forgiving to their servants and workers. He warned those employers who do not treat their workers well and said, "The one who treats his slaves badly will not enter Paradise." 47

Going one step forward the Holy Prophet $(S A W)$ once said that the employer should treat his employees like his children. A famous report is quoted from him, "No person who mistreats his slaves will enter Paradise." Companions asked, "O! Messenger of Allah, did- you not tell us that this nation will have more slaves and orphans than any other nation?" He said: "Yes, so be as kind to them as you are to your own children." 48

Islam does not allow entrepreneurs to make money at the cost of safety and health of their employees. The employer cannot be righteous as soon as he is not kind and just to his employees. It is not permissible to take that kind of work from a worker that puts him in trouble. Employers should not compel workers to do unsafe acts and should not force them to work in such an environment or circumstances that may result in injury or could be fatal.

\footnotetext{
${ }^{44}$ Muhammad Ramzan Akhter, “An Islamic Framework for Employer-Employee Relations,” 213.

${ }^{45}$ Ziba Kazemian, and Bahram Ghamgosar, "The Relationship between Islamic Management and Organizational Entrepreneurship," Australian Journal of Basic and Applied Sciences, vol. 5, no. 10 (2011): 969.

${ }^{46}$ Al-Qur'ān: al-Qasas 28:27.

${ }^{47} \mathrm{Abu}$ Eisa Muhammad Ibn Eisa, Jami At-Tirmidhi, Translated in English by: Abu Khaliyl, (Riyadh: Darussalam, Publishers and Distributers, $1^{\text {st }}$ Edition, 2007), Chapters On "Righteousness And Maintaining Good Relations With Relatives From The Messenger Of Allah," Chapter 29., "What Has Been Related About Treating The Servant Well," (1946), 55/4.

${ }^{48}$ Muhammad Bin Yazeed, Ibn-Majah al-Qazwini, Sunan Ibn Majah, Translated in English by: Nasiruddin al-Khattab (Riyadh: Darussalam, Publishers and Distributers, Saudi Arabia, $1^{\text {st }}$ Edition, 2007), Chapters on Etiquette, Chapter 10. "Beneficence Towards Slaves," (3691), 36/5.
} 
Hayat, Occupational Safety in Islamic Perspective

\subsection{Manageable Work Load}

Employer should avoid assigning excessive work that may be beyond the capacity of the worker. The nature of the work should be such that worker can perform easily. ${ }^{49}$ It has been instructed in Qur'ān that, "And I do not want to put you in any trouble; you will find me, Insha Allah (God-willing) one of the righteous." 50

In the light of the above quoted verse, an employer cannot be righteous if he does not save his employees from excessive work load. The excessive workload can be dangerous for safety and health of employees. A tired and overburdened employee can easily make a mistake which may lead to fatal accident. Holy Prophet $(S A W)$ has been reported to have said to Abu Dharr al-Ghifari regarding to treat his servant, "You should not overburden them with what they cannot bear, and if you do so, help them (in their hard job)." 51

Islam regards that the worker should work till he is able to do the job without taxing himself unduly. ${ }^{52}$ It is the principle of God that He does not obligate anyone beyond his capacity. ${ }^{53}$ In the eyes of Allah an entrepreneur cannot be 'righteous' until and unless he has the desire to protect his employee from the unnecessary burden of labour. ${ }^{54}$

\subsection{Preventing the Potential Hazards}

Allah has reminded the people of faith to be preventive in their lives and said, " $\mathrm{O}$ you who believe, fear Allah, and everybody must consider what he (or she) has sent ahead for tomorrow." ${ }_{55}$ The message of the verse is about preparation for the Hereafter; however, there is also general message in this verse that people should prepare for the challenges of tomorrow rather than waiting for them to approach them suddenly. Prophet Muhammad $(S A W)$ has been reported to have said, "When anyone of you go to bed, he should shake out his bed with the inside of his waist sheet, for he does not know what has come on to it after him." 56

This instruction of Holy Prophet $(S A W)$ is relevant to the risk assessment and hazard elimination in all matters of daily life including workplace. It makes it obligatory to eliminate hazards which otherwise could harm them. The employer shall take adequate

${ }^{49}$ Akhter, “An Islamic Framework for Employer-Employee Relations,” 210.

${ }^{50}$ Al-Qur'ān: al-Qasas 28:27.

${ }^{51}$ Sahih Al-Bukhari, "The Book of (al-Itq) Manumission (of Slaves)," Chapter 15, "Slaves are your brothers, so feed them with the like of what you eat," (2445), 415-16/3.

${ }^{52}$ Hakim Said, The Employer and the Employee: Islamic Concept, 100.

${ }^{53}$ al-Baqarah 2:286.

${ }^{54}$ Toseef Azid, "The Concept and Nature of Labour in Islam: A Survey," Review of Islamic Economics, Vol., 9, No. 2 (2005): 101

${ }^{55}$ al-Hashr 59:18.

${ }^{56}$ Sahih Al-Bukhari, “The Book of Invocations," Chapter. 13, (6320), 187-88/8. 
Hayat, Occupational Safety in Islamic Perspective

steps to prevent accidents and injury to health. They must take necessary steps to minimize hazards inherent in the working environment. The employer shall establish systems to prevent detect and respond to potential hazards to the safety and health of its employees. An employer according to Islamic injunctions has to take precautionary measures against industrial hazards. ${ }^{57}$ Employer should provide his workers all Personal Protective Equipment (PPE's) to safeguard them against potential hazards. The provision of necessary protective equipment to the employees should be free of cost because it is the responsibility of the employer to provide safe working conditions to the workers.

\subsection{Safety and Health Awareness Training Programmes}

Safety and health training programs and sessions are necessary to create awareness about importance of safety and health among the workers. It is the process by which organizations can provide necessary skills and knowledge their employees need to carry out their jobs in safe manner. The training programs shall develop such qualities in the employees they need to be more productive as well as safety conscious thus contributing more and more to the organizational objectives. Today all the successful and expanding organizations invest lot of money on the training and development of their employees. ${ }^{58}$ Islam seeks its adherents to acquire sufficient knowledge of the things in order to change their present condition as it is stated, "Surely, Allah does not change the condition of a people unless they change themselves." 59

Islam presents a just approach towards duty of the entrepreneur to train his labour force and arrange the basic education for them, which is necessary for work. ${ }^{60}$ Training and development is considered to be as the basic needs of the working class. As saying of the Prophet $(S A W)$ is narrated by Abu Musa al-Ashari, "He who has a slave-girl and educates and treats her nicely and then manumits and marries her, will get a double reward." 61

The values of kindness and benevolence promote the idea of training and development of employees in an organization. ${ }^{62}$ The employer should provide its employees regular and recorded safety and health training to enhance their knowledge about safe work procedures and skill base.

${ }^{57}$ Ramzan Akhter, “An Islamic Framework for Employer-Employee Relations,” 210.

${ }^{58}$ Carrell, Personnel: Human Resource Management, 15.

${ }^{59}$ Al-Qur'ān: Ar-Ra'ad 13:11.

${ }^{60}$ Toseef Azid, "The Concept and Nature of Labour in Islam: A Survey," 100.

${ }^{61}$ Sahih Al-Bukhari, "The Book of (Al-Itq) Manumission (of slaves)," Chapter 14, "The Superiority of him who teaches his slave-girl good manners," (2544), 415/3.

${ }^{62}$ Mohammad Branine and David Pollard, "Human Resource Management with Islamic Management Principles: A Dialectic for a Reverse Diffusion in Management," Personnel Review Vol. 39, no. 6, (2010): 723.

JOURNAL OF ISLAMIC THOUGHT AND CIVILIZATION

Volume 8 Issue $1 \quad 2018$ 


\subsection{Compliance with the Government Regulations}

Every employer while establishing its undertakings gives an oath that he shall abide by all the government rules and regulations. In order to keep its promises he must acknowledge all the rules and regulations of the country in which he is operating his business as it is his religious duty to fulfil duties. ${ }^{63}$ Every country in her labour code imposes some obligations upon the employer regarding safety and health of its employees and the surrounding communities. It is the legal as well as religious obligation upon the employers to fulfil these contracts. Failing to honour those regulations could lead to bad consequences not only in this world but also in the Hereafter.

\subsection{Responsibility of the Workers}

In Islam the socio economic relations are established on the philosophy of obeying the competent authority. In economics and business terms, it is the responsibility of all employees to obey all legal and reasonable orders from those in position of authority among them. Allah says, "O you who believe, obey Allah and obey the Messenger and those in authority among you." 64

To be a good Muslim and a good employee it is necessary for an individual to work according to the prescribed work instructions provided by the employer. He must ensure the compliance to safety rules of the business. It is for their own benefit to accept willingly all the safety procedures to be safe at the workplace. The safety conscious and responsible behaviour of the employees shall help in the creation of safe working conditions in the workplace.

\subsection{Safety and Health as Charity}

The act of helping one another in the form of charity (sadaqah) stands high in the teachings of Islam. There are many forms of charity; one among them is to remove hardships from the way of others according to the Hadith of Prophet SAW ${ }^{65}$ which is applicable in the creation of safe and healthy working environment. On the part of employers, it is their duty to remove all hardships from the workplace in the form of potential hazards to the safety and health of their employees. On the other hand, it assigns duty to the employees to point out and eradicate all hazardous and unsafe working conditions. This mutual responsibility of eliminating unsafe working conditions shall bring blessings of Allah in the workplace.

${ }^{63}$ Al-Maidah 5:1.

${ }^{64}$ Al-Qur'ān: Al-Nisa 4:59.

${ }^{65}$ Muslim bin al-Hajjaj, Sahih Muslim, Trans., Nasiruddin Al-Khattab, "The Book of Zakat," Chapter 16. The word charity (Sadaqah) may apply to all good deeds Ma'ruf, (2335), 54-55/3 (Riyadh: Darussalam, Publishers, Distributers, Saudi Arabia, $1^{\text {st }}$ Edition, 2007). 
Hayat, Occupational Safety in Islamic Perspective

\section{Conclusion}

Occupational safety in Islamic perspective is much more than compliance with the state legislations labour codes. It goes beyond the practices of health and safety at the workplace to achieve material gains only. Islamic perspective of occupational safety and health is based on the dignity of human beings. According to Islamic teachings it is the birth right of all individuals to live safely and happily in this world. Going ahead of compliance to the government regulations it creates a safe working environment based on the principles of brotherhood, mutuality, cooperation, mercy, kindness and benevolence. Safety and security of employees in the workplace is backed by the concept of Hereafter which creates sense of responsibility in the minds of policy makers. Maintaining safety at the workplace is responsibility of both the employer and the employees. Creation of a safe working environment is not only need of modern business but also a religious obligation and Divine Calling. Violation of this religious obligation is sin and will result bad consequences not only in this world but also in the Hereafter. In contrast, fulfilling the Divine obligations shall result in countless blessings on the workplace which lead to greater productivity and prosperity of the business. Employers working under the Islamic instructions of business and trade should make their workplace safer and secure because it is connected with the Pleasure of Allah. If an employer is well-wisher to his employees Allah shall place him in high esteem.

\section{Bibliography}

Abbas J. Ali. Islamic Perspectives on Management and Organization: New Horizons in Management. Cheltenham: Edward Elgar Publishing Inc., U. K., 2005.

Abdullah, Osman Chuah, Muhammad Shuhaimi bin Haji Ishaq. "Conceptual Framework of Good Management from the Islamic Perspective." International Journal of Business and Management Studies vol. 4, No. 1, 2012.

Abu Eisa, Muhammad Ibn Eisa, Jami' at-Tirmidhi. Translated in English by: Abu Khaliyl Riyadh: Darussalam, Publishers and Distributers, Saudi Arabia, $1^{\text {st }}$ Edition, 2007.

Akhter, M. R. "An Islamic Framework for Employer-Employee Relations." The American Journal of Islamic Social Sciences. Vol. 9, No. 2, 1992.

(al-) Bukhari, Abu Abdullah, Muhammad Ibn Ismail. Sahih Al-Bukhari, English Translation by Dr. Muhammad Muhsin Khan. $1^{\text {st }}$ edition. Darussalam Publishers and Distributers, Riyadh, Saudi Arabia, 1997.

Branine, Mohammad. and David Pollard. "Human Resource Management with Islamic Management Principles: A Dialectic for a Reverse Diffusion in Management," Personnel Review. Vol. 39, No. 6, 2010.

Carrell, M. R., and Kuzmits, F. E., Personnel: Human Resource Management. Columbus: Merrill Publishing Company, $2^{\text {nd }}$ edition, 1986. 
Hayat, Occupational Safety in Islamic Perspective

Hakim, Muhammad Said. The Employer and the Employee: Islamic Concept. Karachi: Dar al-Fikr al-Islami, Pakistan, $1^{\text {st }}$ edition, 1972.

Kabir, Hassan. and Hippler William J., "Entrepreneurship and Islam: An Overview." Economics in Practice Vol., 11 (2) 2014.

Kamali, Mohammad Hashim, "Human Dignity in Islam." Paper presented at the International Conference on Pathway of Human Dignity: From Cultural Tradition to a New Paradigm, jointly organized by Europe Science Foundation (ESF) and Linkopeng University, Vadstenna, Sweden, $1^{\text {st }}$ November, 2007.

Kazemian Ziba. and Bahram Ghamgosar. "The Relationship between Islamic Management and Organizational entrepreneurship." Australian Journal of Basic and Applied Sciences. Vol. 5, No. 10. 2011.

Khaliq Ahmed, "Challenges and Practices in Human Resource Management of the Muslim World." The Journal of Human Resource and Adult Learning. Vol. 4, No. 2, December, 2008.

Labour Force Survey, 2014-15, Islamabad: Government of Pakistan, Statistics Division Pakistan Bureau of Statistics, 2015. http://www.pbs.gov.pk/content/labour-forcesurvey-2014-15-annual-report

Legge, Karen. Human Resource Management: Rhetorics and Realities. New York: Palgrave Macmillan, Anniversary edition, 2005.

Mantoux, Paul. The Industrial Revolution in the Eighteenth Century. London: Methuen and Company Limited, n. d.

McFarland, Dalton E. Personnel Management: Theory and Practice. New York: Macmillan, 1968.

Muhammad Bin Yazeed Ibn-Majah. Sunan Ibn Majah. Translated in English by: Nasiruddin al-Khattab. Riyadh: Darussalam, Publishers and Distributers, $1^{\text {st }}$ Edition, 2007.

Muslim bin al-Hajjaj. Sahih Muslim. Translated in English by Nasiruddin Al-Khattab. Riyadh: Darussalam, Publishers, Distributers, Saudi Arabia, ${ }^{\text {st }}$ Edition, 2007.

Naqvi, Syed Nawab Haider. Ethics and Economics: An Islamic Synthesis. Leicester: The Islamic Foundation, United Kingdom, $1^{\text {st }}$ Edition, 1981.

-. Individual Freedom, Social Welfare and Islamic Economic Order. Islamabad: Pakistan Institute of Development Economics, $1^{\text {st }}$ Edition, 1981.

Rokhman, Wahibur. "The Effect of Islamic Work Ethics on Work Outcomes." EJBO Electronic Journal of Business Ethics and Organization Studies Vol. 15, No 1, 2010.

Sison, Payos and Zorilla. Personnel Management in the $21^{\text {st }}$ Century. Quezan City: Personnel Management Association of Philippines, Rex Printing Company, Inc., Philippines, $7^{\text {th }}$ edition, 2003. 
Tayed, Munir. "Islamic Revival in Asia and Human Resource Management." Employee Relations, vol. 19, No. 4, 1997.

Toseef Azid. Mehmet Asutay. Umar Burki. "Theory of the Firm, Management and Stakeholders: An Islamic Perspective." Islamic Economics Studies vol. 15, No. 1, July 2007.

-. "The Concept and Nature of Labour in Islam: A Survey." Review of Islamic Economics. vol. 9, No. 2, 2005.

Usmani, Muhammad Taqi. An Introduction to Islamic Finance. Karachi: Arham-Shamsi Publication, 2004.

Witzel. Management: The Basics. New York: Routledge, 2004.

Yadollahpour, Behrouz. "Human Dignity and its Consequences in the Holy Qur'ān." International Conference on Sociality and Economics Development (IPEDR). vol. 10, No.1, 2011. 